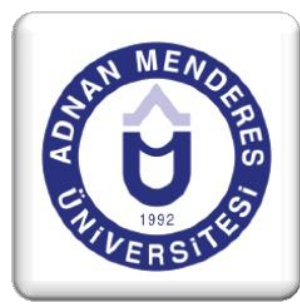

\title{
Osmanlı İktisadi Modernleşmesinde Liberal Tezler
}

\section{Liberal Theses on Ottoman Economic Modernization}

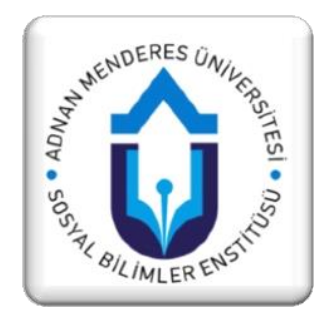

Levent ODABAŞI ${ }^{1}$

\section{Özet}

Osmanlı Devleti, tarih sahnesine çıktığı günden yıkılışına denk düşen döneme kadar çeşitli fikirsel akımların kendi bünyesindeki tezahürlerine ev sahipliği yapmıştır. Özellikle, Imparatorluğun 19. yüzyılda içinde bulunduğu durum, tam da bu çağa özgü siyasi ve iktisadi akımların ve düşünme şekillerinin kendi etkisini oldukça sert bir biçimde ifade ettiği ve hem imparatorluk hem de toplumlar nezdinde karşıllk bulduğu bir ana denk düşmekteydi. Bu minvalde, Osmanlı Devleti'nin modernleşme sürecine eşlik eden ve henüz nüve halinde olan iktisadi liberalizm anlayışı, bu çalışmanın odak noktası olmuştur. Bu çerçevede, Osmanlı yönetim kademesinde bulunan kişiler ve önemli tarihi şahsiyetler temel referans noktası teşkil edecektir.

Anahtar Kelimeler: Osmanlı Imparatorluğu, liberalizm, serbest ticaret, mülkiyet

\begin{abstract}
From the time of getting on the stage of the history, to the period of downfall The Ottoman Empire hosted the manifestations of various currents of thoughts. Especially, in the 19th century, the situation of the Empire coincided with the time in which, the political and economic currents and the ways of thinking expressed their impacts strongly and by the Empire and the communities they were internalized. In this context, the focal point of this paper is the concept of economic liberalism which accompanied the modernization of the Ottoman Empire and was just a seed then. Also in this scope, the persons in the ruling layer of the Empire and historically significant individuals are the main reference points.
\end{abstract}

Keywords: The Ottoman Empire, liberalism, free trade, property

\footnotetext{
${ }^{1}$ Araş. Gör., Adnan Menderes Üniversitesi, İIBF Siyaset Bilimi ve Kamu Yönetimi Bölümü
} 


\section{19. Yüzyll'da Modernleşme ve İktisadi Liberalizmin Doğuşu}

19. yüzyıl, Osmanlı Devleti için pek çok farklı alanda değişim ve dönüşümün sağlanmaya çalışıldığı, devletin özellikle idari ve mali konularda önemli sayılabilecek bazı kararlar aldığı bir yüzyılı temsil eder. Aslında, değişim çabalarının 17. yüzyıla kadar götürülebileceği şeklindeki bir argüman yanlış olmayacaktır. Çünkü Osmanlı yenileşmesi, henüz o yüzyıllarda adı konmamış olsa bile, kendisini var edecek ve gündeme getirecek koşulları bulmuştu. Osmanlı da yaşanan şeyin bir adı konacaksa eğer bu, 'değişmenin değişmesi' olabilirdi (Ortaylı, 2013: 15). 19. yüzyılın hemen başı ise, İmparatorluğun bu yüzyılda değişimin ve yenileşmenin sancılarını iyiden iyiye hissedeceğinin bir işareti gibiydi. Padişahın yetkilerini ilk kez paylaştıran 1808 tarihli Sened-i İttifak, bu yüzyılın bir yüzyıldan daha uzun geçeceğinin belirtisi olmuştu. Gerçekten de 1839 yılında Hatt-1 Hümâyun'un yani Tanzimat Fermanı'nın Gülhane parkında okunması, daha sonra ise Sultan Abdülmecid döneminde 1856 tarihli Islahat Fermanı'nın ilanı mevcut dönemin hareketli ve sancılı geçiyor olduğunun birer göstergeleriydiler. Her iki fermanın da Osmanlı yenileşmesinde ve modernleşmesinde kritik bir aşamaya denk düştügünü söylemek mümkündür. Bununla birlikte, dönemin şartları itibariyle düşünüldüğünde bu hamleler ilerici gözükmektedir. Öyle ki, gerek Tanzimat ve gerekse Islahat Fermanı, kişi hak ve hürriyetlerinin korunmasında, can, mal, namus güvenliğinin sağlanmasında ve eşitlik konusunda bir takım yenilikler, güvenceler getirmekteydi. Askeri alanda yeniliklerin kök salması da yine bu şartlar dâhilinde olmaktaydı. Osmanlı Tüm bu yenileşme hareketleri düşünüldüğünde, iktisadi alanın bu hareketli atmosferden uzak kalacağını düşünmek yanlış olurdu.

Osmanlı iktisadi modernleşmesi, değişimin mevcut şartları altında kendisine bir yer bulma mücadelesini 19. Yüzy1l boyunca sürdürmüştür. Özellikle 1826-1908 arası dönem, iktisadi liberalizmin kendisini farklı şekillerde ifade ettiği bir dönem arz eder. 1826 y1lı öncesi Osmanlı ekonomisine damgasını vurmuş olan tekellerin varlığ 1 ve korumacı politikalar, 1826 yılı sonrasında ve özellikle 1860 yılına kadar Osmanlı pazarlarının dışa açılması ve iç pazarın da bir şekilde serbest bırakılması, ticaretin serbestleştirilmesi gibi uygulamalarla terk edilmeye başlanmıştır. 1860 ile 1908 arasındaki dönem ise yine liberal iktisat politikalarının hâkimiyetini hissettirdiği ama bir taraftan da korumacı politikaların varlığını sürdürdüğü döneme tekabül eder. 1908-1912 yılları arasında ise liberal iktisat politikaları kendini iyiden iyiye hissettirse de, I. Dünya Savaşı'nın başlamasıyla korumacı iktisadi politikalar üstün gelmiş ve 'milli iktisat' düşüncesi zihinlere iyiden iyiye yerleşmeye başlamıştır (Quataert, 2007: 888). Osmanlı iktisadi yapısının tradisyonalizm(gelenekçilik), provizyonizm(ithalatın serbest birakılması, ihracatın k1s1lması) ve gelirde sabitlik(fiskalizm) üçlemesiyle çevrelendiği düşünüldüğünde yukarıda verilen dönemselliklerin ne derecede öneme haiz olduğu görülebilecektir (Dinçaslan, 2012: 81). Tanzimat ve Islahat Fermanlarının bu noktada getirdiği serbestlik ve rahat ortam, Osmanlı'da pek çok düşünce insanının ilgisini çekmiş ve devlet adamları arasında da bu tarz yenilikçi iktisadi akımların yaygınlaşmasını sağlamıştır.

Osmanlı devlet adamları, Osmanlı iktisadi sistemine getirmek istedikleri yenilikleri Batı toplumlarını ve Batılı devletlerin iktisadi yapısını ve kurumlarını gözlemleyerek gerçekleştirmek ve meşrulaştırmak niyetindelerdi. Öyle ki, onlara göre, Batı toplum ve ekonomisinin harcında bireycilik(individüalizm), liberalizm, serbest girişim, parlâmentarizm ve kapitalizm vardır. Rejim, ekonomik sınıfların çıkarlarına göre biçimlendirilir ve bireycilik beraberinde herkesin yararına olur. Osmanlı'da ise bürokrasi ve militarizm esastır, sınıflar bulunmaz. Toplumda gücü elinde bulunduranlar yarattıkları mekanizmalarla bireyin özgürlük ve girişim ruhunu kısıtlar, özel mülkiyete getirilen kısıtlamalarla ekonomik girişimlerle palazlanabilecek sermaye birikimini olanaksızlaştırır. Eğitim sisteminden yönetim sitemine kadar bütün devletsel kurullar ona göredir (Berkes, 1978: 389).

$\mathrm{Bu}$ anlayışın sonucunda ise toplum içinde yükselmenin, statü sahibi olmanın ya da en basitinden zengin olmanın tek yolu devlette bir görev edinmek anlayışı olmuş ve Osmanlı bir kamu devleti haline gelmiş; bununla birlikte devlet bir kazanç kapısı haline gelmiştir. $\mathrm{Bu}$ ise girişimcilik ruhunun gelişmesini önlüyor ve insanları pasif uyrukluğa mahkûm etmekteydi(Özlem, 2004: 459). Bu durum, Osmanlı Devleti'nde memur zihniyetinin egemen hale gelmesindeki başlıca sebepti. Çalışanının ileriki kısımlarında ayrıntılı olarak görüşlerine yer verilecek olan Prens Sabahattin'e göre, Osmanlı Devleti toplumcu bir yapıya sahipti. Böylesi bir toplum tipi ise beraberinde, kişisel çaba ve itibarın yeğlenmediği, devletin her şeyin kaynağı olduğu, işbölümü ve uzmanlaşmanın olmadığı ve herkesin memurluk peşinde koştuğu bir yapıyı getirmişti. Prens Sabahattin'e göre insanların memuriyet peşinde 
koşmasının asıl sebebi memuriyet hayatının rahatlığı, kayırılmanın güvencesidir. Onlar için çalışmak ve üretmek gibi değerler kayırılma ve rahatlık karşısında önemsizdir. Devlet dairelerinde bu kadar memur istihdamının olması ve insanların memuriyete yönelmesinin sebebini burada aramak gerekir. $\mathrm{Bu}$ da beraberinde, tek başına hayatta kalabilen insanların çoğalmasına, her şeyi devletten bekleyenlerinin sayısının artmasına sebebiyet vermektedir (Sencer, 1965: 19-29).

\section{Tanzimat Dönemi Liberal Yaklaşımları}

Tanzimat Dönemi önder kişiliklerinden olan Mustafa Reşid, Âli ve Fuad Paşalar da dönemin modasına ayak uydurarak liberal düşünce ve görüşler öne sürerler. Bu döneme dikkatle bakıldığında hâkim olan temel yaklaşımın liberal bir yönetim anlayışı ve ekonomi olduğu göze çarpar. Fuad Paşa ve Âli Paşa'nın amaçladıkları temel şey mülkiyetin serbest bırakılmasıdır. Nitekim Osmanlı Devleti'nde son dönemde pek çok defa sadrazamlık görevinde bulunan Fuat Paşa'nın vasiyetnamesinin serbestiyet ekonomi modeli ile idari yapının yönetimi tavsiye edilirken, dinle devlet işlerinin birbirinden kesin bir biçimde ayrılmasının gerekliliği fikri işlenir ${ }^{2}$. Yine 19. yüzyılda sadrazamlık görevinde bulunmuş olan Âli Paşa da vasiyetnamesinde, padişaha 1lımlı bir liberalizm programı önerir. Bu metinde ithalatın kısılması yönündeki devlet müdahalesi gereğine karşılık, devletin maaşlı memurlarınca yönetilen fabrikalardan vazgeçilmesi, çünkü devlet fabrikalarının hem çok masraflı olduğu; hem de gelişmekte olan özel yerli sanayii boğduğu belirtilir (İnsel, 2001: 44).Mülkiyetin serbest bırakılması, onlara göre, ekonomin hızlı bir yükselişe geçmesiyle sonuçlanacaktır. Fakat bu gelişmenin bireyden başlayarak tamamlanacağını da söylemek gerekir. Bunun için gerekli adımları da atarlar. Tanzimat Fermanı'nın ilân edilmesinden sonra, kişilerin mallarına ölümlerinden sonra ya da görevlerinden alınınca el konulması gibi sermaye birikimini engelleyen önemli bir engel olan müsadere sistemi kaldırılır. Arazi Kanunnamesi(1858) ile imparatorluğun büyük kısmını kapsayan devlet malı arazidüzeninden özel mülkiyete geçiş başlatılır.

Tanzimatçı devlet adamlarına göre ticaret özgür bırakılarak liberal bir anlayış çerçevesinde sürdürülmelidir. Ticaret serbestisi onlar için her ülkenin olduğu gibi Osmanlı Devleti'nin de peşinden gitmesi gereken bir amaçtır. Bu aşamada bankacılığın başlaması onlar için ticaret serbestisinin önündeki engellerden birinin yıkılmasını temsil eder. Bugün halâ yaşayan özel teşebbüsler kuruluşlarından birisi olan Şirket-i Hayriye vapur işletmesi onların eseridir. Sanayi alanında ise öncelikle devlet eliyle sanayileşmeyi denerler. Günümüzdeki organize sanayi bölgeleri uygulamasına benzer fabrikalar kurarlar. 1840'lardan 1860'l y yllara kadar süren bu girişimlerin olumsuz sonuçlanması üzerine özel sektöre destek vermek ve bir özel sektör yaratmak amacıyla esnafı birleştirerek, şirketler oluşturmak ve gümrük duvarlarını yüksek tutarak bu oluşumu himaye etmek yolunu tutarlar. Bununla birlikte yabancı sermayenin İmparatorluk sınırlarından içeri girmesi onların düşünceleri arasında önemli yer tutar. Bununla birlikte özel sektörün gelişebilmesi adına, devletin elindeki fabrikaların özel kesime bırakılması da talepler arasındadır. Özetle, liberal ekonomi ilkelerinden biri olan 'minimal devlet' anlayışını öne sürerek devletin ekonomik hayattan tasfiyesini talep ederler.

Tanzimat, pek çok yönüyle İmparatorluğun liberal bir iktisat programı çizmesi için gerekli koşulları az veya çok oluştursa da yeterli olamayacaktır. İmparatorluktaki bilgi birikiminin yokluğu, ekonominin esaslarını bilen, kavrayan insanların bulunmayışı Avrupa karşısındaki teknolojik yetersizlikler ve rekabet ne devlet eliyle sanayileşmeye ve ne de bir özel sektörün filizlenmesine imkân tanır. Yapılan hemen bütün teşebbüsler yarım kalır Bütün bu eksik ve yetersizliklerine rağmen Tanzimat Dönemi yeni ve dinamik bir genç kuşağın doğmasına ve yetişmesine vesile olur. Tanzimat'ı ve Tanzimatçıları eleştirmekle yola çıkan bu yeni kuşak farklı fikir ve ideolojik yaklaşımların ortaya çıkmasını sağlar. İbrahim Şinasi (1824-1871), Avrupa'yı tanıyan bir aydın olarak, 1862 yılında çıkarmaya başladığı Tasvir-i Efkâr Gazetesi ile akıl, kanun ve devletin görevleri üzerine liberal fikirler ileri sürer. O'na göre devlet toplumun çıkarlarını korumalıdır. Ekonomik görüşleri ise hür teşebbüsten yanadır. Nasıl doğayı etkileyen kanunlar varsa ekonomiyi etkileyen kanunlar da bulunmaktadır, sermaye ve özel tasarrufun önemine değinmektedir. ${ }^{3}$ Şinasi'nin Tasvir-i Efkâr Gazetesi’ndeki "ki insan bu vasıtalarla

\footnotetext{
${ }^{2}$ http://atam.gov.tr/wp-content/uploads/01-sarika-gedikli.pdf Erişim Tarihi: 18.09.2014

${ }^{3}$ http://yunus.hacettepe.edu.tr/ mehmets/liberalizmindogusu.pdf Erişim Tarihi: 20.09.2014
} 
ömrü boyunca çalışsa bile akıl yoluyla yapamadığı işleri, doğa az vakitte pek kolaylıkla gerçekleştirir" cümlesi, onun Adam Smith'in doğal düzen ilkesinin geçerliliğini vurguladığı cümlelerinden bir tanesidir(Öztürk, 2007: 93).

\section{Namık Kemal ve Serbest-i Ticaret}

19. yüzyılın ikinci yarısından itibaren hem siyasi hem de iktisadi alanda Osmanlı'yı etkisi altına alan liberalizm furyası, Namık Kemal nezdinde de karşılığını bulabilmiştir. Siyasi hürriyet peşinde şekillendirdiği düşüncelerinin yanı sıra Namık Kemal, serbest ticaret fikrini de etkili bir şekilde savunan düşünce insanlarının da başında gelmekteydi. Namık Kemal (1840-88), sadece anayasalı bir yönetimin siyasi hürriyetin garantisi olacağını değil, fakat aynı zamanda serbest ticareti savunması bakımından da liberal doktrinin etkisi altında kalmıştı. Ondan yaklaşık bir kuşak önceki bir başka düşünce ve edebiyat adamı İbrahim Şinasi (1824-71) de teşebbüs hürriyetinden yana fikirler ileri sürmüş ve devletin toplumun çıkarlarına hizmet etmesi gerektiğini savunmuştur. ${ }^{4}$

Namık Kemal, çeşitli yazı ve makalelerinde sürekli biçimde 'Serbest-i Ticaret'i savunmuştur. Ona göre, Osmanlı ülkesinde bir sermaye birikimi yoksa bunun nedeni servetin olmaması değil; sanayi, ticaret ve bankaların gelişmemesi nedeniyle bir birikimin ortaya çıkmamasıdır. 'Maarif, ticaret ve zanaat kollarında ileri giderek birikim sorunu çözülebilecektir (Çavdar, 2003: 22). Namık Kemal özellikle vergi olayına bir 'serbesti' olarak bakmaktadır. Ona göre vergi:

- Ancak gerekli ve zorunlu harcamaları karşılamak için alınmalıdır.

- Devletin gördügü kesin gereksinim üzerine alınan vergi, ülkede yaşayan tüm kişilere yaygın olmalidir.

- Vergide kar oranı kesinlikle ölçü olarak kabul edilmemelidir.

- Dolaysız vergiler, dolaylı vergilere yeğ tutulmalıdır.

- Vergi, belirli bir düzeye kadar artan oranlarda alınmalıdır.

Eserlerinde bakıldığında açıkça görülebileceği üzere, liberal devlet anlayışı, Namık Kemal'in tüm yazılarında egemendir. Yazdıklarına dönüp bakıldığında dikkati ilk çeken noktalardan bir tanesi 'minimal devlet' anlayışının Namık Kemal'in siyasi düşüncesinde önemli bir yer işgal ettiğidir. Ona göre devlet, tıpkı liberal devletin 'bekçi devlet' ile eş anlamlı tutulması anlamına gelecek şekilde, eğitim, sağlık ve genel yapması gereken işlerin ötesinde yer almamalıdır. Namık Kemal'e göre, Osmanlı ülkesindeki gerilemenin durdurulabilmesinin yollarından bazıları eğitimin çağdaş niteliklerde devam ettirilmesi ve serbest ticaret kurallarının egemen olduğu bir ekonomik gelişme yolunun takip edilmesidir.

Namık Kemal'in ekonomik tercihi görüldüğü gibi çok açıktır: kapitalistleşmek. Osmanlı'nın geleceği bu sürece bağlı olarak düşünülmüsşür. 19. yüzyılın ortalarından itibaren hemen her alanda ortaklaşılan amaç kapitalist olmaktı. Kimsenin bu gayeden kuşku duyduğu söylenemezdi. Farklı kesimlerin arasındaki tek tartışma noktası bunun nasıl yapılacağı yönündeydi. Kimi bu konuda serbest ticareti ödünsüz uygulamayı ögütlemekte, kimisi ise sanayimizi güçlendirinceye kadar himaye yöntemlerine başvurmanın zorunlu olduğunu söylemektedir (Çavdar, 2003: 24). Fakat Namık Kemal, tercihini serbest ticaret ilkelerinden yana kullanarak korumacı politikaların karşısında yer alacaktı.

Korumac1lığa ve himayeciliğe şüpheyle bakarak serbest-i ticareti savunan Namık Kemal, yazdıklarında, tekel demek olan "yedd-i vahit" usulüne şiddetle karşı çıkar. Ona göre serbest ticaret, İmparatorlukta da geçerli olmalıdır. Serbest ticaretin eksikliğinin, İmparatorluğun geri kalmasındaki en önemli sebeplerden biri olduğunu ifade etmesinin yanı sıra özel girişimciliğin ve özel şirketlerin bulunmamasını da eleştirir.

\footnotetext{
${ }^{4}$ http://www.liberal.org.tr/sayfa/liberalizm-ve-turkiyede-liberal-egilimler-mustafa-erdogan,344.php? Erişim tarihi: 15.01.2014
} 


\section{Sosyalizm ve Komünizm Karşısında Sakızlı Ohannes Paşa}

Sakızlı Ohannes Paşa(1830-1912), 1850'li yılların başından itibaren sistematize ettiği düşünceleriyle Osmanlı'nın kapitalizm yolunda hızla ilerlemesini savunmuş ve ticaret serbestisinin önemli savunucularından birisi olmuştur. Beynelmilelci Burjuva yaklaşımının Osmanlı İmparatorluğu'ndaki iki tipik temsilcisinden(diğeri Cavit Bey'dir) biri olan Sakızlı Ohannes Paşa, ekonomiye devlet müdahalesine ve korumaya şiddetle karşı çıkarak içte ve dişta liberal iktisat politikalarının partizanlığını yapmıştır (Boratav, 2008: 25). Ohannes Paşa, Mekteb-i Mülkiye'de verdiği iktisat derslerinde de liberal iktisadın ilkelerini öğretmiş ve klasik liberal öğretinin sıkı bir takipçisi olmuştur. Bilinen o ki, 19. yüzyılın ikinci yarısı, iktisadi düşüncenin serpilmeye başladığı ve liberal iktisadi modelin savunucularının yavaş yavaş sahnede yerini almaya başladığı bir dönem olmuştur. Sakızlı Ohannes Paşa'nın da kendi düşünce sistematiğini bu dönemde ortaya çıkarması bir tesadüf değildir.

Türkiye'de siyasal düşüncenin gelişmesinde ve tanıtılmasında önemli mihenk taşlarından biri olan Mekteb-i Mülkiye'de iktisat dersleri veren Sakızlı Ohannes Paşa, Türkiye'de klasik iktisat teorisini anlatan dersler verir. Sakızlı Ohannes Paşa'nın ise iktisadi liberalizm düşüncesinin Türkiye'deki temellerini atan düşünür olduğu söylenebilir. "Milletlerin Zenginleşmesi Biliminin Kaynakları" (Mebadi-i İlm-i Servet-i Milel) adlı kitabın da yazarı olan Ohannes Paşa'ya göre Osmanlı devletinin iktisadi kalkınması için mülkiyet hakkına ve girişim özgürlüğüne dayalı, açık ve rekabetçi bir iktisadi yapı gerekliydi. Paşa temel yaklaşımına uygun olarak, ekonomide korumacılık, devletçilik ve tekelin yanlış olduğunu ileri sürmüştür". "Mebadi-i İlm-i Servet-i Milel" isimli eseri daha isminden başlayarak Adam Smith'in "Ulusların Zenginliğì" adlı eserinin ve onun liberal iktisat anlayışının Türkiye'deki temsilcisidir. İlm-i Servet* isimli eserinde Ohannes Paşa, servetin bölüşümü, üretimi, dolaşımı ve tüketilmesi gibi temaları ele almıştır. Eserde rekabet ise, 'Eşyayı, birikimi, karı ve hasılatı ne tayin eder? Bu sorunun yanıtı serbest rekabettir' şeklinde tanımlanır (Çavdar, 2003: 25).Onun için rekabetin serbest olması oldukça önemli bir noktadır. Ohannes Paşa'ya göre, ulaşım ve iletişim hizmetleri bile özel şirketlerin ellerine teslim edilmelidir. Liberal iktisat öğretisinin meşru görmediği korumacılık, kamuculuk ve tekel düzenine karşı cephede yer alır. Bununla birlikte, devletin fiyat belirlemesi(narh) usulüne de soğuk bakmaktadır. Klasik liberal öğretinin temel nüanslarından birisi olan özel mülkiyet, Sakızlı Ohannes Paşa'nın da üzerinde önemle durduğu konulardan bir tanesidir. Onun için ortak mülkiyet, insan doğasına aykırı ve eleştirilmesi gereken bir noktadadır. Sakızlı Ohannes 'in savunduğu mülkiyet biçimi ise özel mülkiyettir. $\mathrm{O}$, henüz o sıralarda Avrupa'da hala tartışılmakta olan sosyalizmi eleştirir ve onun tam da karşısında yer alır. Sosyalizm, özel mülkiyetin tam tersi olması, insan doğasına aykırı yapısı, devlet müdahalesinin açıktan bir biçimde savunuculuğu yapması noktaları itibariyle Sakızlı Ohannes Paşa'nın tepkisine neden olacaktır.

Sosyalizme ve Komünizme karşı olan Sakızlı Ohannes, hükümetin bireylere iş bulmasını, refahı yaygınlaştırmak için işsizlik ve yoksulluk yardımları yapmasını doğru bulmaz. Bu nedenle de, hükümete tanınan ekonomiye karışma, müdahale etme yetkisine de karşı çıkmaktadır. Ona göre, devlet hiçbir biçimde ekonomiye karışmamalıdır (Çavdar, 2003: 26).O, '’kâffe-i efrad-1 beşerin bilcümle emval ve emlakten müştereken ve mütesaviyen hissemend olması ve binaenaleyh mülkiyet-i şahsiyye ve hatta aile ve veraset esaslarının fesh olunması..." şeklinde kurduğu cümlesiyle sosyalizmi tanımlamış ve sosyalizmin şahsi mülkiyet, miras, aile kavramı gibi önemli hislerden ve sahipliklerden yoksun olduğunu dile getirmiştir ${ }^{6}$. Ona göre, sosyalizmde hükümetin bir takım gereksiz müdahalelerde bulunması, insanların çoğunluğunu rahatlığa ve eylemsizliğe itmektedir. Bu da, halkın istekliliğine ve gayretine ket vurmaktadır. Sonuçta ise, bireylerin girişimde bulunma istekleri törpülenecek ve kamu harcamaları bütün bunların neticesinde hiç olmaması gerektiği kadar boşu boşuna artacaktır.

Mülkiyet hakkı, Sakızlı Ohannes Paşa için serbest ticaret anlayışının kurucu unsurlarından biridir. Servetin üretim koşulları sağlanmadığında ise servetin çoğaltılabilmesi gibi bir imkân ortaya çıkmayacaktır. Bu açıdan mülkiyet, her şeyin başlangıcıdır. Bununla birlikte mülkiyet hakkı, insanın

\footnotetext{
${ }^{5}$ http://www.liberal.org.tr/incele.php?kategori=MTg=\&id=NDY2 Erişim Tarihi: 24.09.2014

${ }^{6} \mathrm{http} / / /$ osmanli-arsivi.blogspot.com.tr/2008/03/80-yldnmnde-bolevik-ihtilalinin-osmanl.htmlErișim Tarihi: 24.09.2014

* O yıllarda iktisat karşılığı olarak kullanılmıştır. İlm-i Servet, eğer klasik iktisat öğretisi dikkate alınacak olursa ‘iktisat bilimi’ anlamına gelmektedir.
} 
kendine ait olanı istediği gibi kullanabilmesi, yani üzerinde tasarruf hakkının bulunabilmesi anlamına gelir. Eğer mülkiyet hakkı garanti altına alınırsa, uygarlıkların gelişmesinin önündeki en büyük engellerden bir tanesi yok olmuş olur. Bu nedenle komünistlerin ortak mülkiyete dayalı ekonomik sistemleri uygarlığı ileri götürmeyecek ve servetin birikiminin sağlanmasını geciktirmesi açısından zararla sonuçlanacaktır.

Sakızlı Ohannes, sonuç olarak, 1850'li yıllardan beri gerek iktidardaki aydın-bürokratlar, gerekse 'Yeni Osmanlılar' diye nitelendirdiğimiz ilerici ve özgürlükçü genç aydınlar tarafından bölük pörçük dile getirilmiş konuları, çağının ekonomi bilimi doğrultusunda sistematize etmiş ve Batılılaşmanın tek yolu olarak görülen kapitalistleşme için serbest-i ticaret politikasını önermiştir (Çavdar, 2003: 27). İttihat ve Terakki'nin merkeziyetçi fikirlerinin karşısında hiç de azımsanmayacak sayıda olan grubun arasında yer alarak her alanda liberalizmi savunmuştur. Nitekim bu dönemde liberalizmi savunan Sakızlı Ohannes Paşa'nın Türkiye'de iktisadi liberalizmin temellerini attığı kabul edilir (Erdoğan, 2001: 32). Ohannes Paşa, bir ülkenin kalkınması ve refahı açısından liberal ekonominin dışında hiçbir yolun olmadığına inanmıştır.

\section{5. İktisadi Liberalizmin İzinde: Cavit Bey ve Anti-Himayecilik}

İttihat ve Terakki Cemiyeti'nin ekonomik görüşleri 1908-1914 yılları arasında liberal ekonomiye yönelik bir çizgi izler. Bu ekonomi politikasının mimarı "İttihat ve Terakki'nin mali siyasetinin nâzımı ve ruhu telâkki edilen" Mehmet Cavit Bey (1875-1926)'dir. Cavit Bey, II. Meşrutiyet'in ilânından sonra dönemin ünlü felsefecilerinden olan arkadaşları Rıza Tevfik ve Ahmed Şuayib ile birlikte Türkiye'de liberal ve pozitivist düşünce hareketinin en önemli yayın organlarından biri kabul edilen Ulûm-1 İktisâdiyye ve İctimâiyye Mecmuası'nı 1908-1910 yılları arasında 24 sayı olarak çıkarmıştır. Kaleme aldığı eserlerinde, Osmanlı İmparatorluğu'nun kalkınmasının ancak, dünya ekonomisiyle bütünleşmesi yoluyla olabileceğini ve bu amaçla yabanci sermayenin ülkeye gelmesi gerektiğini savunmuştur. Himayeciliğe karşı çıkmış, İmparatorlukta özel teşebbüsün geliştirilmesi gereğine dikkati çekmiştir. ${ }^{7}$ Bununla birlikte Mehmet Cavit Bey'in sistemli olarak savunduğu iktisat politikaları, serbest-i ticaret, tarımsal ihracata dayalı ihtisaslaşma, yabancı sermayeye karşı açık kapı, piyasalara devletin âdem-i müdahalesi unsurlarına dayanıyordu (Boratav, 2008: 26).

Ohannes Paşa'yı izleyen ve Ohannes Paşa'nın iyi bir takipçisi olan son dönem devlet adamlarından Mehmet Cavit Bey de s1kı bir liberal iktisatçı olarak kabul edilmektedir (Sayar, 2002: 570). Cavit Bey iktisadi görüşlerini "İlm-i İktisat" adlı kitabında toplamış ve "Ulum-1 İktisadiye ve İctimâiyye Mecmuası"nı çıkaranlar arasında yer almıştır. Bahsi geçen dergi, Meşrutiyet liberal anlayışının kuramsal yayın organı olmak yolunda hızla ilerlemiştir (Toprak, 1995: 11). Dört ciltten oluşan İlm-i İktisat yani İktisat Bilimi isimli kitabında Cavit Bey, kendi görüşlerini düzenli bir şekilde ortaya koymuştur. Ulûm-i İktisâdiyye ve İctimâiyye Mecmûas1, mübadele serbestisinin desteklenmesi, uluslararası ticaretteki tün engellemelerin kaldırılması ve toplumsal refaha ulaşılabilmesi için şahsi çıkar anlayışının göz önünde bulundurulması gibi hususları konu edinmekteydi (Toprak, 1995: 12).Cavit Bey, yazılarında, Osmanlı Devleti'nin ekonomik olarak ilerlemesinin ve gelişmesinin ancak dünya ekonomisi ile bütünleşmesi ve bu amaçla yabancı sermayeyi ülke sınırları içerisine dâhil etmesi yoluyla olabileceğini söylemiştir. Ticaret serbestisini savunarak, iktisadi korumacılığa karşı çıkmış ve özel teşebbüsün önemi vurgulamıştır (Erdoğan, 2001: 32).Cavit Bey, korumacı politikaların ülkede genel serveti artırmayıp halkın zararına olarak sadece birkaç kişinin zengin olmasına sebep olacağını ifade etmiştir (Cavit, 2001: 275).

Mehmet Cavit Bey’e göre, sanayinin himayesi yanlışların başında gelmekteydi. Ona göre, himaye edilen sanayinin ürünleri yabancı ülkelerden gelen o cins ürünlerden pahalı çıktığı halde, herkes memleket ürününü tüketmeye mecbur bırakılmıştı. Bütün işçi, zanaat erbabı vb. gibi bireyler o sanayinin böyle zor ile korunması uğrunda adeta bir ceremeyi ödemek zorunda bırakılmış ve yerli ürünle yabancı ürün arasındaki fiyat farkı oranında zarara uğramıştı. Böylece belirli bir grubun açıktan aldıkları kar oranında bütün halk ve hepsinden fazla fukara ve işçi yığınları zararı çekecekti (Çavdar, 2003: 26).

\footnotetext{
${ }^{7}$ http://yunus.hacettepe.edu.tr/ mehmets/liberalizmindogusu.pdf Erişim Tarihi: 02.10.2014
} 
Mehmet Cavit Bey'in iktisadi liberalizme bakışı, sermaye ve iş bölümü hakkındaki yazdıklarına bakarak anlaş1labilir. Ona göre, "Dünyanın neresinde olursa olsun sermayesi bol olan ve iyi kullanılan, iş bölümüne riayet edilen, makineler kullanan, emeğin payını verimliliğine göre belirleyen ülkeler gelişir, aksi durumda bulunanlar ise geriler"(Çavdar, 1992: 88). Bir piyasa ekonomisi savunucusu olarak Cavit Bey, toplumların iktisadî faaliyetlerinde işbölümü yapmak zorunda olduğunu ifade etmiştir (Eroğlu, 2008: 268).

Mülkiyet hakkının, insanları çalışmaya sevk eden en birinci etken olduğu fikrini öne süren Cavit Bey, mülkiyetin en önemli ortaya çıkış sebebinin sosyal fayda ile şahsi fayda olduğunu ifade etmiş, mülkiyet hakkının hem fertlerin, hem de cemiyetlerin menfaatlerine uygun olduğuna değinmiştir. Özel mülkiyetin varlığ fertlerin gayretini artırmakta, bu da fertlerin zenginleşmesine ve dolayısıyla cemiyetin servetinin büyümesine neden olmaktadır. Bununla birlikte, eğer üreteceğimiz mal ve eşyada başkalarının mülkiyet ve hâkimiyet hakkı olacağını bilirsek çalışmayız. Fertlerin gayretli çalışması ise mülkiyet hakkının temin edilmesine bağlıdır (Cavit, 2001: 58).

Cavit Bey piyasa-devlet görev ayırımında; özgürlük, özel mülkiyet ve serbest rekabetin cari olmasını arzu etmiş, devlete düşen görevin ise hakemlik olup, anlaşmazlıkları çözmek olduğunu ifade etmiştir(Eroğlu, 2008: 269). Klasik liberal öğretinin serbest rekabet, girişim özgürlüğü, özel mülkiyet, iş bölümü gibi kavramlarını benimseyen Mehmet Cavit Bey, yukarıda verilen cümlede de görüleceği gibi, devlete sadece oyun tahtasındaki hakemlik görevini vermektedir. Bu açıdan devlet, minimal olandır. Asgari bir devlet müdahalesi, Mehmet Cavit Bey'in düşünce sistemini oluşturan kilit noktalardan birini oluşturmaktadır

Sonuç olarak denilebilir ki, Mehmet Cavit Bey'in görüşlerinin, özgürlük, özel mülkiyet, rekabet gibi kavramlara vurgu yapması itibariyle Manchester Okulu'nun görüşlerine benzer olduğunu söylemek doğru olur (Çakmak, 2011: 161).Bununla birlikte, Mehmet Cavid Bey’in ekonomik görüşlerinin II. Meşrutiyet'in hemen sonrasına damga vurduğunu söylersek yanlış olmayacaktır. 1908'den hemen sonra, kabineye giren ilk gerçek İttihatçının Mehmet Cavit Bey olması bir tesadüf değildir. Çünkü İttihatçılar, ekonomik duruma klasik liberal bakış açısıyla yaklaştılar. Geleneksel engelleri kaldırmak ve ticari işlemlere ve mülkiyete ilişkin mevzuatı modernleştirmek suretiyle, ticaret ve sanayinin büyümesini teşvik etmeyi amaçladılar. İttihat ve Terakki Cemiyeti, serbest ticareti destekliyor, ancak Osmanlı İmparatorluğu'nun hammadde üreticisi bir çevre ülke konumuyla Batı Avrupa'nın liberal devletlerinden ya da Amerika'dan esasta daha zayıf durumda olduğunu henüz görmüyordu. Mehmet Cavit Bey'e göre ise, yabancı yatırım ve dışarıdan ithal edilecek iş yönetim bilgisi ve tecrübesi çok önemliydi. Her firsatta bunların teşviki için elinden geleni yaptı. Hatta Japon hükümetine başvurarak uzman gönderilmesini istedi (Zürcher, 2012: 188). Tüm bu çabalar, Mehmet Cavit Bey için, iktisadi liberalizmin İmparatorluğun kalkınmasına olacağını düşündüğü faydanın neticesindeydi. Fakat 1914 yılının ardından gelecek savaş, Mehmet Cavit Bey'in karşı çıktığı korumacı politikaların tekrar gündeme gelmesine sebep olacak ve liberal iktisat düşüncesi tekrar gündeme gelmek için uzun y1llar bekleyecektir.

\section{Memurluk Zihniyeti, İlm-i İçtimave Asgari Devlet: Sultanzade ya da Prens Sabahattin}

Osmanlı ülkesinde liberalizm sözcüğü telaffuz edildiğinde ilk akla gelen isimlerden bir diğeri de hiç şüphesiz Prens Sabahattin ve onun dâhil olduğu çevredir. 1877 yılında İstanbul'da doğan Prens Sabahattin, Mahmut Paşa ile Sultan Abdülmecid'in kızı olan Seniha Sultan'ın oğludur. Osmanlı'da şecerenin baba tarafından belirlenmesi durumu göz önünde bulundurulduğunda Prens Sabahattin için 'Prens' unvanının değil de 'Sultanzade' unvanının kullanılması daha doğru olacaktır (Durukan, 2004: 145). Prens unvanını kullanan Sabahattin'in, bunu Avrupa'da bir itibar ele etmek için kullandığına dair tezlere de rastlamak mümkündür(Berkes, 1978: 389).Eklenmesi gerekir ki, 1900'lerde ferdiyetçi kapitalist modelin en önemli savunucularından biri olan Prens Sabahattin, Le Play'in 'Science Sociale' doktrinine bağlıdır (Kılıç, 2010: 3). İleride de bahsedileceği üzere, Le Play etkisinde oluşturduğu fikri yapıya da İlm-i İçtima adını verecektir. Prens Sabahattin, kimi zaman Sultan Abdülhamit, kimi zaman da İttihat ve Terakki istibdadı sebebiyle ömrünün önemli bir kısmını kaçarak geçirmiştir. Nitekim Cumhuriyet'in ilanından sonra 'hanedan üyelerinin yurt dışına çıkarılmasına yönelik kanun' uyarınca Türkiye'yi bir kez daha terk edecek ve 1948 yılında İsviçre'de ölecektir. Prens Sabahattin, Osmanlı 
İmparatorluğu'nun fiili ve zihni iktisadi değişiminin öncülerinden biri olacak ve liberalizmin en önemli savunucularından biri olarak tarihteki yerini alacaktır.

Eğer tam da bu noktada bir ön kabul ile başlanacaksa denilebilir ki, Jön Türk hareketi içinde etkileri günümüze kadar ulaşabilen en önemli düşünce akımı Prens Sabahattin ve grubuna aittir. Öyle ki, Prens Sabahattin, imparatorlukta âdem-i merkeziyetçi bir idare kurup bireysel teşebbüsü teşvik etmek ve aydınların devlet memuriyeti yerine fayda getiren işlere girmesini sağlamak amacıyla imparatorluk yapısını baştan aşağı değiştirmeyi tasarlamaktaydı (Karpat, 1996: 35).Çünkü onun için ilerleme, ne devlette ne de cemaatte aranabilirdi. İlerleme, tam da devletin ve cemaatin yapısı göz önüne alındığında, kendisini onun karşıtında bulabilirdi ancak. İşte bu nokta, Prens Sabahattin'in diğer düşünce akımlarından ve özellikle Jön Türk'ün egemen olan düşüncesinden kopuşuydu. Sabahattin, Jön Türkler içinde bir istisna oluşturuyordu, çünkü değişim ve ilerlemenin motorunu devlette değil, bireyde görüyordu; asgari düzeyde bir devlete ve İmparatorluğu canlandırmak için serbest girişimin gücüne inanıyordu (Zürcher, 2012: 139).

“Türkiye Nasıl Kurtarılabilir?” adlı bir kitabı da bulunan Sabahattin özel teşebbüs taraftarı olmakla beraber, diğerlerinden farklı olarak, iktisadi görüşlerini bireyci bir toplumsal teoriyle temellendirmiştir ${ }^{8}$. Prens Sabahattin, her alanda bireyciliği savunan, girişimci özellikler taşıyan bireylerin desteklenmesini savunmaktaydı. Ona göre, Osmanlı Devleti'nin kurtuluşu buna bağlıdır. Onun için, bireyci toplumlar komüniteryen toplumlara göre daha üretken, girişimci ve bağımsız karakterlidirler. Bu nedenle, bütün diğer doğu toplumları gibi cemaatçi bir toplumsal yapısı bulunan Osmanlı Devleti'nin bunalımdan çıkabilmesi bireyselliğin gelişmesi gerekir. Ayrıca, verimsiz bürokratik mekanizmalar ortaya çıkaran merkeziyetçiliğin terk edilmesi ve idarenin âdem-i merkeziyet ilkesi doğrultusunda yeniden düzenlenmesi şarttır.

Prens Sabahattin'in bizzat kuruculuğunu üstlendiği Teşebbüs-i Şahsi ve Âdem-i Merkeziyet Cemiyeti'nin 1906 yılında yayınlanan programı şöyleydi; “Siyasî ıslahat yapılarak yerinden yönetim sağlanacaktır. Vilayet meclisi üyeleri halk tarafindan seçilecektir. Merkezde halk tarafindan seçilecek bir meclis teşkil edilecektir. Osmanlı halkının hak eşitliği sağlanacaktır. Yerel yöneticiler halkın nüfus dağllımina uygun olarak, farklı etnik ve dinî oranlara göre seçilecektir.". Buna göre, Prens Sabahattin'in düşünceleri, devletten bağımsız olarak kişilerin kişisel yeteneklerini kullanabilmeleri anlamında teşebbüs-i şahsilik düşüncesini ve devlet yönetiminde âdem-i merkeziyet talep eden liberal fikirleri savunmaktayd ${ }^{9}$.

Prens Sabahattin'e göre doğu toplumları ile batı toplumlarının arasındaki fark, bütüncülük-bireycilik arasındaki farka tekabül eder. Bu fark göstermektedir ki, doğuda cemaat, batıda ise birey üstündür. Dolayısıyla bu zihniyet farkı, Osmanlı'da girişimci kapitalist bir sınıfın oluşmasına engel olmuştur. Prens Sabahattin'e göre memur adayı olmak ve geleceğini bunun üzerine kurmak, girişimciliğin önündeki en önemli engellerden bir tanesidir. Bunun için yapılması gereken, insanların, çevrelerinde bir takım değişikliklere gitmesi, memur zihniyetinden kurtulması ve üretim ilişkilerinde girişimci ruhu içselleştirebilmeleridir.

Yukarıdaki paragrafta verilen doğu-batı ayrımı tam da Prens Sabahattin'in 'İlm-i İçtima' anlayışına denk düşer gibidir. Çünkü Prens Sabahattin, bir toplumsal totalitenin iyileştirilebilmesi için o bütünün içtimai yani sosyal yapısının(bünyesini) tanınması/bilinmesi gerektiğini iddia eder. Bu şekilde bir girişimde bulunmadan yapılacak olan herhangi bir iyileştirme, yolunu kaybedecek ve yanlış yerlere varacaktır. O nedenle tek yol içtimadan geçmektedir. (Ülken, 2001: 336) Böylece Prens Sabahattin, Osmanlı'da liberalizmin hâkimiyetinin sağlanması için gerekli 'arkhe'ye yani ilk nedene sahip olmuştur. Çünkü ona göre, iki farklı toplum tipi olan doğu-batı toplumlarından Osmanlı için geçerli olanı doğu tipi toplumdu. Böylesi bir toplum bireysellikten, girişimci ruhtan, iktisadi hürriyetten mahrumdu. Ancak batı tipi toplumlar için geçerli olabilecek olan bu kavramlar, Osmanlı ülkesinde karşı1ık bulmamaktaydı. Öyle ki, batı tipi toplumların temel karakteristiği, ferdiyetçilik, teşebbüs-ü şahsi, girişim özgürlüğü ve özel mülkiyet gibi odak noktalarına sahipti. Doğu tipi, yani Osmanlı'nın da içinde bulunduğu kategorideki ülkeler de ise, her şeyi devletten bekleyen, sorumsuz, kendini idare etmekten aciz, girişimci yönü gelişmemiş cemaat üyesi bulunmaktaydı. Osmanlı çağdaşlaşması için,

\footnotetext{
${ }^{8}$ http://www.liberal.org.tr/incele.php?kategori=MTg=\&id=NDY2 Erişim Tarihi: 07.10.2014

${ }^{9} \mathrm{http}$ ://atam.gov.tr/wp-content/uploads/01-sarika-gedikli.pdf Erişim Tarihi: 08.10.2014
} 
Prens Sabahattin'in deyişiyle, tecemmüi toplumdan infiradi topluma yani bütünden bireye geçilmelidir (Berkes, 1978: 390).

Prens Sabahattin'in İlm-i İçtima yaklaşımı, onun daha sonra Osmanlı ülkesinde savunuculuğu yapacağı liberal tezleri için önemli bir dayanak noktası oluşturmuştur. Teşebbüs-ü şahsi, asgari devlet, özel mülkiyet, girişim özgürlüğü, bireyin özgürlüğü gibi kavramlar içtima yaklaşımının birer sonucu gibidirler. Ona göre Osmanlı'da varlığı tümüyle hissettiren bürokrasi, militarizm, hükümdarın yerleşikliği gibi nedenler bireyin özgürlük alanını daraltmakta ve özel girişimi engellediği gibi gereken sermaye birikimini de geciktirmektedir (Berkes, 1978: 391). İşte tüm bu çerçevenin içerisinde girişimcilik yok oluyor, insanlar sırtını devlete yaslayarak pasifliğe sürükleniyordu. $\mathrm{Bu}$ ise, bireyci toplum fikriyle taban tabana zit bir karakteristiğe sahipti (Özlem, 2004: 459). Tüm bunların sonucunda, memur toplum iş başındaydı.

Osmanlı toplumunda memurluk, itibar gören ve güven teşkil eden bir hüviyete sahipti. Merkeziyetçi yapısıyla bu duruma son derece müsait olan Osmanlı'nın rekabete, girişimciliğe, bireyciliğe, risk almaya, zenginleşmeye kendi bünyesinde yer vermeyişi de bireyin gelişmesinde ve kendi ayakları üzerinde kalmasında bir engel teşkil etmekteydi. Memurluğun yüksek itibar ve gelir sunmasına ek olarak rahat ve kolay bir uğraşı olması, halk nazarında onu cazip hale getirmiştir. Ailelerin çocuklarını memur yapmak, dünya gözüyle görmek istedikleri saadetlerinden biri olmuştur. Memurluk itibar ve güven unsuru olarak görüldügünden, aileler kızlarını memura vermeyi tercih ediyorlardı (Aytaç, 2006: 10). İşte bu rahatlık içerisinde Osmanlı ülkesinde yaşayan insanlar, ataleti içselleştirmişler ve gözlerini tek işveren olarak devlete dikmişlerdi. Prens Sabahattin ise bu durumu eleştirerek, bütün bu dengenin insanları çalışmadan kazanmaya, kayrılma arzusuna sevk ettiğini söylemiştir. Bireyin, toplum dışında kendisini var edebilecek koşullara sahip olamamakla birlikte, kurulu düzenin, onlar için durumun bu haliyle yani stabil halde kalmasına gönülden rıza gösterdiklerini ifade etmiştir. Mesleki işbölümünün olmadığı, uzmanlaşmanın gerçekleşmediği, herkesin devlet kapısında memur olmak için sıraya girdiği böylesi bir toplum, çağın gereklerine ayak uyduramayacak ve daha fazla himayeye ve 'koltuk çıkamaya' bel bağlayan insanların yetişmesine neden olacaktır. Böylece memuriyet zihniyetinden gelen alışkanlıklar, kar ve girişimi hala algılayamamış Osmanlı ülkesinde gerilemenin sürdürülmesinde temel etkenlerden biri olacaktır.

Sonuç olarak denilebilir ki, Prens Sabahattin düşüncesinde Osmanlı iktisadi gerilemesinin temel nedenlerinden bazıları olarak bireyciliğin gelişmemesi, İlm-i İçtima kavrayışının bir cevap bulamamas1, girişimci ruhun törpülenmesi, özel mülkiyetin hayata geçirilememesi ve toplumu neredeyse bütünüyle sarmış olan memuriyet anlayışı örnek gösterilebilir. Prens Sabahattin, II. Meşrutiyet sonrası 1914 yılına kadar sürdürülmeye çalışılan iktisadi liberalizm programının öncülerinden biri sayılsa da İttihat ve Terakki tarafından sakıncalı görülmekten kurtulamayacaktır. Fakat denilebilir ki, Prens Sabahattin'in düşüncesi İttihat ve Terakki'yi bir tehlike olarak görenler tarafından destek bulabilmiş ve yankısını sürdürmeye devam etmiştir. Örnek olarak II. Meşrutiyetin ilanından sonra, Osmanlı Ahrar Fırkası, İttihat ve Terakki'nin siyasal hayata egemen oluşunu gelecek için sakıncalı gören bir grup aydın tarafından kurulacaktır. Partinin programı, Prens Sabahattin beyin görüşlerini savunacak ve Prens Sabahattin'in bir zamanlar lideri bulunduğu 'Teşebbüs-ü Şahsi ve Âdem-i Merkeziyet' taraftarlarının görüşlerini, öte yandan da baskıya karşı kuvvetler dengesini isteyeceklerdir (Teziç, 1976: 184).Daha sonra ise, II. Meşrutiyet'in 1909-1911 yıllarında, İttihat ve Terakki'ye karşı gelişen muhalefet, nihayet 21 Kasım 1911'de 'Birleşik Muhalefet Cephesi' olarak Hürriyet ve İtilaf Fırkası'nın doğuşuna yol açacaktır. Fırka'nın fikir yapısı âdem-i merkeziyetçi Prens Sabahattin'in görüşlerine dayanacaktır. Özellikle Teşebbüs-ü Şahsi ilkesi, ülkenin gelişmesi, sermaye birikiminin sağlanması için, 'Teşebbüsat-1 Hususiye ve Şahsiye’ye Arız Olan' engellerin kaldırılması ve 'Ecnebi Sermayedarın Memlekete Duhulü 'nün gerekliliği üzerinde özenle durulacaktır (Teziç, 1976: 193).

\section{Sonuç}

Osmanlı İmparatorluğu'nun farklı alanlarda yapmaya çalıştığı 1slahatlar ve değişiklikler, bir zorunluluktan çok iç kararın sonucu olarak görülmelidir. Fakat değişim ve dönüşüm çabalarının tamamen iradi bir şekilde yapıldığını söylemek de mümkün değildir. Çünkü Osmanlı İmparatorluğu, her ne olursa olsun, değişen şartların ve genel olarak 'değişen dünyanın' farkındadır. Bu 
değişmenin/yenileşmenin/dönüşümün sadece 19. yüzyıla has olmadığını da burada söylemek gerekir. Değişim, aslında çok önceden başlayan ve adı konulmadan ilerleyen bir süreçten ibaretti 19. yüzyıla kadar. Fakat 19. yüzyıl, değişimin adının yavaş yavaş konulmaya başlandığı, Batı'ya her zaman kuşkuyla bakarak yapılan değişimin içsel bir kararla yapılmaya başlandığı uzun bir yüzyıl olmuştur. İdari, mali ve diğer pek çok alanda girişilen yenileşme hareketi, bu dönemde, iktisadi alanda da kendisini gözle görülür derecede hissettirmiştir. Tek seçenek olarak varlığını bütünüyle hissettirmeye başlayan Batı liberalizmi de işte bu şartlar dâhilinde Osmanlı düşün dünyasını etkisini almaya başlamıştır. Dönem, iktisadi liberal tezlerin siyasetçiler ve yönetici kadrolar tarafından hissedilir bir şekilde dillendirdiği bir dönem olmuştur. Böylece Osmanlı'da iniş ve çıkışlarıyla iktisadi liberalizme ait kavramlar açıktan açığa konuşulmaya başlanmıştır. Elbette ki böylesi bir tartışmanın halk nezdinde tartışılmasını beklemek yanlış olurdu. Keza dönüp dikkatle bakıldığında, döneme damgasını vuran fikir önderlerinin tartışmanın yürütücülügünü yaptığı görülecektir. İniş ve çıkışlar ise İttihatçı düşünce içindeki yöntemle ilgilidir. Öyle ki, kimsenin dönüşümle ilgili bir problemi yok gibidir. Assl problem, bunun ne şekilde yapılacağı üzerinde biçimlenir. Bu durum, 1908 devrimini gerçekleştirenlerin aradan birkaç yıl geçtikten sonra muhalif olan tabakalaşmayı nasıl diskalifiye ettiklerinde açıça görülebilmektedir. Her ne kadar liberal düşüncelere sahip kişilikler bu muhalefet ortamı içerisinde kendilerine yeterince uygun bir alan bulamayıp yurt dışına kaçsalar da, liberalizm, ya bir firka ya da bir cemiyet ile yeniden canlanacak ve gündemden kolay kolay düşmeyecektir.

Osmanlı İmparatorluğu, liberal iktisat ilkeleriyle geç tanışmıştır. Fakat tanıştığı anda da ülkenin içinde bulunduğu ahvale bir sihirli değneğin dokunuşu misali etki ettiğini söylemek mümkün değildir. Yapılan her türlü yenilik, bulunan her yeni fikir ve fikirlerin çatışması sadece belirli bir yönde ilerleme sağlamış ve İmparatorluğun ancak bir süre daha ayakta durmasını sağlamıştır. Özellikle II. Meşrutiyet'in ilanından sonra 1914'e gelindiğinde iktisadi liberalizm geçerliliğini yitirmiş ve hafızalarda derin izler bırakan 'milli iktisat' politikası işlenmiştir. Özellikle 'yerli burjuvazinin yaratılması' sürecinde hem gayri Müslimlerin ticaret hayatından silinmeleri hem de yerli sermayedarın korunması gibi politikalar müdahale yanlısı olmayan liberalizmin tam zittı uygulamalar olarak yer almışlardır. 1914 sonrası dönem, liberalizmin ana ilkelerinin bir kenara bırakılarak 'sermayenin ve girişimcininTürkleştirildiği' bir dönem olarak göze çarpmaktadır. İşte bu koşullar içinde liberal tezler bir müddet daha geri plana itilecektir.

Osmanlı İmparatorluğu'nda 19. yüzyılda gerçekleştirilmeye çalış1lan değişim ve dönüşüm çabaları arasında kendisine yer bulan liberal iktisat öğretisi, her ne kadar İttihatçı düşünce içerisinde şüpheyle karşılanmış olup muhalif kabul edilmiş olsa da, topluma yöne veren yönetici kadrolar tarafindan çözümün ilk odağı olarak görülmüş ve Sakızlı Ohannes Paşa, Mehmet Cavit Bey ve klasik liberal öğretinin en önemli temsilcilerden biri olarak Prens Sabahattin tarafından savunulmuştur. 


\section{KAYNAKLAR}

AYTAÇ, Ö. (2006) "Memurluk Zihniyeti ve Memuriyen Toplum: Prens Sabahattin'in Görüşleri Işığında Bir Çözümleme", Dokuz Eylül Üniversitesi Sosyal Bilimler Enstitüsü Dergisi Cilt 8 Say1:1

BERKES. N. (1978)Türkiye'de Çağdaşlaşma, İstanbul: Doğu Batı

BORATAV, K. (2008) Türkiye İktisat Tarihi 1908-2007, Ankara: İmge

CAVID, M. (2001) İktisat İlmi, İstanbul: Liberte Yayınları

ÇAKMAK, D. (2011) Osmanlı İktisat Düşüncesini Evrimi Societas ve Universitas Gerilimi, İstanbul: Libra Yayınları

ÇAVDAR, T. (1992), Türkiye'de Liberalizm, Ankara: İmge

ÇAVDAR, T. (2003) Türkiye Ekonomisinin Tarihi, Ankara: İmge

DINÇASLAN, M. (2012) “Osmanlı Devleti'nin Kapitalistleşme Sürecinde Farklı İki Aydın Portresi: Ziya Gökalp Ve Mehmed Cavid Bey”, Ekonomi Bilimleri Dergisi, Cilt:4 No:2

DURUKAN, K. (2004) "Prens Sabahattin ve İlmi İçtima, Türk Liberalizminin Kökenleri”, Modern Türkiye'de Siyasi Düşünce, Tanzimat ve Meşrutiyet'in Birikimi, Cilt 1, İstanbul: İletişim

ERDOĞAN, M. (2001) “Liberalizm ve Türkiye Serüveni”,Modern Türkiye'de Siyasi Düşünce, Liberalizm, Cilt 7, İstanbul: İletişim

ERDOĞAN, M. Liberalizm ve Türkiye'de Liberal Eğilimler, http://www.liberal.org.tr/sayfa/liberalizm-ve-turkiyede-liberal-egilimler-mustafaerdogan,344.php? 15.01.2015 tarihinde erişildi.

EROĞLU, N. (2008) İttihatçıların Ünlü Maliye Nazırı Cavid Bey, İstanbul: Ötüken Neşriyat

HAYTA. N. ve ÜNAL, U. (2012) Osmanlı Devletinde Yenileşme Hareketleri, Ankara: Gazi

İNSEL, A. (2013) “Türkiye'de Liberalizm Kavramının Soyçizgisi”, Modern Türkiye'de Siyasi Düşünce, Liberalizm, Cilt 7, İstanbul: İletişim

KARPAT, Kemal H. (1996), Türk Demokrasi Tarihi, İstanbul: Afa

KILIÇ, M. (2010) “Türk Siyasal Hayatında Bir Muhalif İsim ve Hareket: Prens Sabahattin ve Meslek-i İçtima”, Süleyman Demirel Üniversitesi, Sosyal Bilimler Enstitüsü Dergisi, 2010/2 Say1:12

ORTAYLI, İ. (2013) İmparatorluğun En Uzun Yüzyıl1, İstanbul: Timaş

ÖZLEM, D. (2004), Türkiye'de Pozitivizm ve Siyaset, Modern Türkiye'de Siyasi Düşünce, Modernleşme ve Batıcılık, Cilt 3, İstanbul: İletişim

QUATAERT, D. (2007)Osmanlı İmparatorluğu'nun Ekonomik ve Sosyal Tarihi, Cilt 2, İstanbul: Eren Yayınc1lik

SAYAR, A.G. (2002) Yenileşmeden Cumhuriyete Osmanlı İktisat Düşüncesi, Türkler 1600-1914, Cilt 14, Ankara: Yeni Türkiye

TEZİÇ, E. (1976) 100 Soruda Siyasi Partiler, İstanbul: Gerçek Yayınevi

TOPRAK, Z. (1995)Milli İktisat-Milli Burjuvazi, İstanbul: Tarih Vakfi Yurt Yayınları

ÜLKEN, H.Z. (2001) Türkiye'de Çağdaş Düşünce Tarihi, İstanbul: Ülken Yayınları

ZURCHER, E.J. (2012) Modernleşen Türkiye'nin Tarihi, İstanbul: İletişim 